\title{
Failure Analysis in High Pressure Feed Water Heaters and Method to Find the Defect in Tubes
}

\author{
S. Manavalan, Manikandan J, Nakkeeran S
}

\begin{abstract}
The aim of this study is to analyze the causes of tube failure of the high pressure feed water heaters in thermal power plants and to find out the defective tubes in high pressure feed water heaters using simple and economical method.

A feed water warmer is utilized to preheat the kettle feed water in warm power plant. The majority of the feed water radiator utilized in warm power plant is shell and cylinder type. In this kind of feed water warmer, water streaming inside the cylinder and steam consolidating in outside of the cylinder i.e., shell side. The wellspring of warmth utilized in high weight feed water warmer is steam seep from the turbine. The high weight feed water radiators are utilized to improve the thermodynamic effectiveness of the cycle and furthermore diminish the coal utilization of the warm power plant.

Test of the disappointment cylinder were taken to investigate the reasons for cylinder disappointment in high weight feed water radiator by visual review, utilizing tube thickness estimation examination, Examining Mechanical properties and substance structure of the cylinder material and strategies for finding the cylinder disappointment ahead of time to counteract the breakdown of high weight feed water warmers. In light of the above investigations, it is seen that the high weight feed water warmer cylinders disappointment happened because of cylinder external distance across disintegration.
\end{abstract}

Keyword : High pressure Feed water heaters, tube failure, corrosion, erosion.

\section{INTRODUCTION}

In warm power plants, high weight radiators are utilized to warm the feed water utilizing drain or extraction steam. A bit of steam extricated from turbine is called as drain steam or extraction steam. This steam is utilized in high weight warmers to warm the feed water. Inert warmth of this drain steam is used in feed water radiators, else it will lost in condenser with cooling water. Utilizing this warmth vitality, over all cycle effectiveness of the plant is expanded.

In warm power plants, High Pressure ( H.P ) feed water radiators are associated in feed water line between Boiler feed siphon and economizer. There are two sorts of feed water radiators are utilized in warm power plant.

Revised Manuscript Received on August 22, 2019.

S. Manavalan, Department of Mechanical Engineering, Bharath Institute of Higher Education and Research, Chennai, Tamilnadu, India. Email: manavalan.kannan@gmail.com

Manikandan J, Department of Mechanical Engineering, Bharath Institute of Higher Education and Research, Chennai, Tamilnadu, India. Email: kandan.arni@gmail.com

Nakkeeran S, Department of Mechanical Engineering, Bharath Institute of Higher Education and Research, Chennai, Tamilnadu, India. Email: naks_67@yahoo.co.in

\section{A. Open feed water radiators}

\section{B. Shut feed water radiators}

For the most part shut sort feed water warmers are utilized in warm power plants to warm the feed water and furthermore open sort feed water radiator is utilized for feed water de-air circulation reason. The open radiator in such a framework is called deaerator.

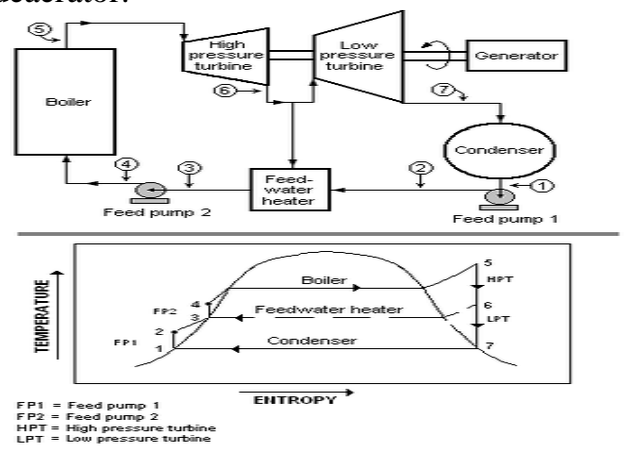

Figure1 - Feed water heater cycle

In shut feed water warmer, water courses through the cylinders in the radiator and drain steam consolidates outwardly of the cylinders in the shell. The shut feed water radiator has three zones[1],[3],[5].

\section{De-Superheating Zone}

The approaching steam enters this zone, surrendering the vast majority of its superheat to the feed water leaving from the warmer.

\section{Sub Cooling Zone}

The approaching steam enters this zone, surrendering the vast majority of its superheat to the feed water leaving from the warmer.

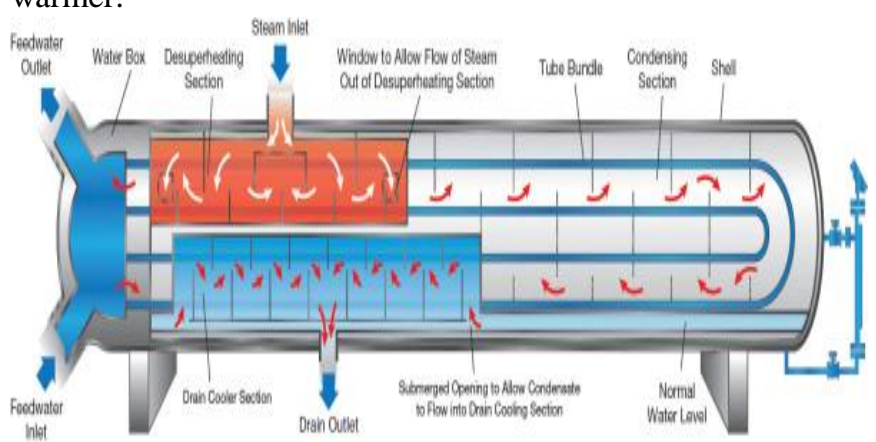

Figure 2 - Different zones of

Heater

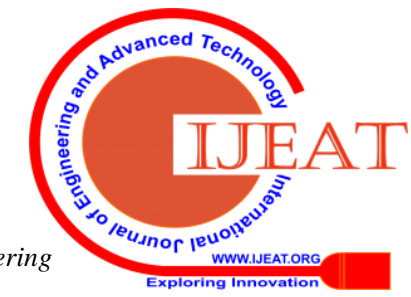




\section{Condensing Zone}

All feed waters have this zone. The majority of the steam is dense here, and any outstanding non condensable gases must be evacuated. An enormous level of the vitality included by the radiator happens here.

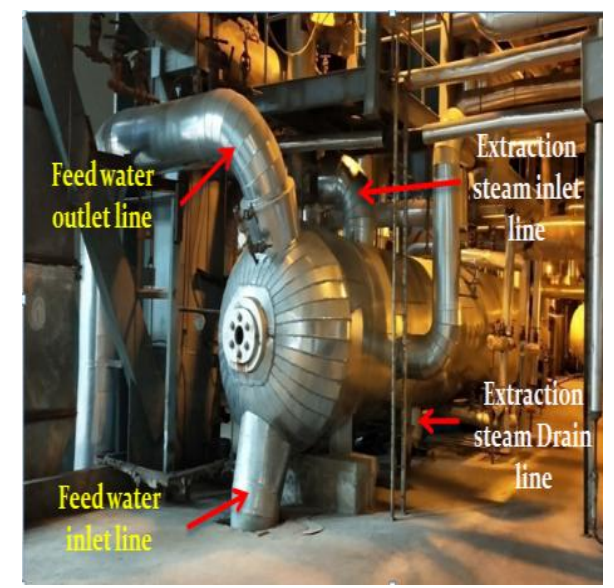

Figure 3 - High pressure feed water heater

The mechanical properties and the compound piece of both aluminum and magnesium amalgams are given in the tables 1 and 2 .

\section{Temperature Profiles}

The temperature profiles for a high-weight feed water warmer which gets superheated steam separated from a high-weight turbine.

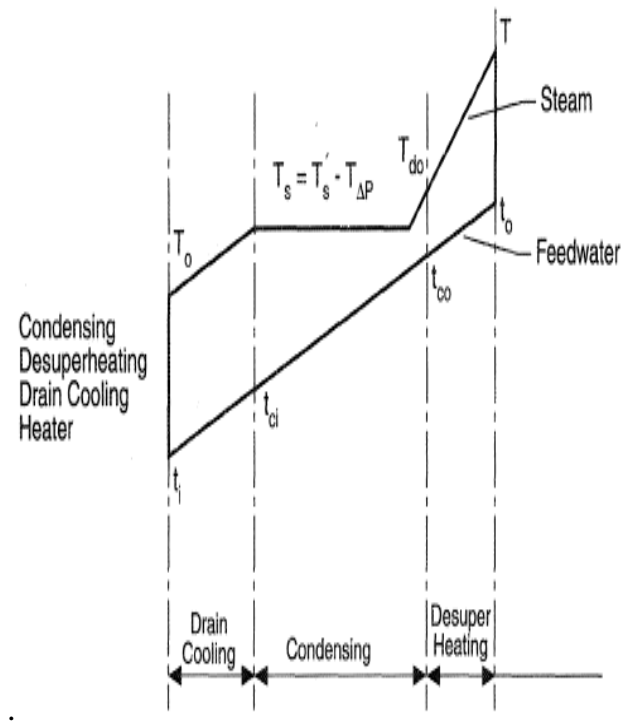

Figure 4 - Temperature graph

\section{TUBE FAILURE MECHANISM}

In general, High Pressure feed water heaters are fails due to one of the following reasons.

\section{A.General Corrosion}

General erosion is the most well-known type of consumption [3]. It happens by a synthetic or electrochemical response that returns consistently over the whole surface. Because of this synthetic response, thickness of the cylinder turns out to be dynamically more slender and in the long run comes up short due to the pressure loadings forced on it.

\section{B. Crevice Corrosion And Pitting}

Cleft erosion is a restricted consumption of a metal surface[1]. It might happen, because of permeable scales, erosion items, mud or trash, appended to the cylinder surfaces. At the point when the creviced territories are little, the subsequent limited consumption may look like setting assault. Chloride assumes a basic job in setting and fissure consumption. The chloride esteem in feed water must to be kept up underneath under 1.2 $\mathrm{ppm}$, if the estimation of chloride increments over the referenced level the cylinders will have confined erosion. The anxiety incorporates lingering stresses and administration stresses. Leftover pressure may happen during an assembling procedure or establishment. Administration stress is brought about by an extension stress, circle pressure, or bowing pressure. For hardened steel materials, this incorporates the nearness of concentrated chlorides $[4,5]$. Chlorides enter in to the Feed Water framework when there are condenser tube disappointments.

\section{Galvanic Corrosion}

Galvanic consumption of a metal that happens on account of an electrical contact with progressively honorable metal in a destructive arrangement.

\section{D.Erosion - Corrosion}

Disintegration erosion is a type of confined consumption [1]. It is likewise called as water side impingement assault. It happens on the water side of the cylinders because of mechanical disturbance of the defensive oxide film. In zones, where the disturbance force at the metal surface is sufficiently high to make mechanical interruption[2],[4],[6].

\section{E. Stress Corrosion Cracking}

Stress erosion breaking (SCC) that happens when a defenseless composite is worried in pressure in a specific destructive condition [3]. At any rate one condition, all compounds are defenseless to Stress erosion splitting. The development of stress consumption breaking is moderate. In High Pressure feed water radiators, SCC disappointments are started for the most part on the steam side of the cylinder. In water side, constrained quantities of Stress Corrosion Cracking disappointments just was watched.

\section{METHODOLOGY AND ANALYSIS OF TUBE FAILURE}

The following test methods and analysis have been performed to investigate the failure of high pressure feed water heater tubes.

\section{A.Eddy Current Test}

Vortex Current Testing (ECT) is a nondestructive test procedure dependent on inciting electrical flows in the material being examined and watching the association between those flows and the material. 
Swirl flows are produced by electromagnetic loops in the test, and checked at the same time by estimating the test's electrical impedance.

Eddy Current Test were carried out in defective high pressure feed water heater to find the defective tubes using probes. During this test, thicknesses of the tubes were measured and weaker tubes were identified. Most of the tubes affected in De - Superheating zone area was noticed during this Eddy Current Test

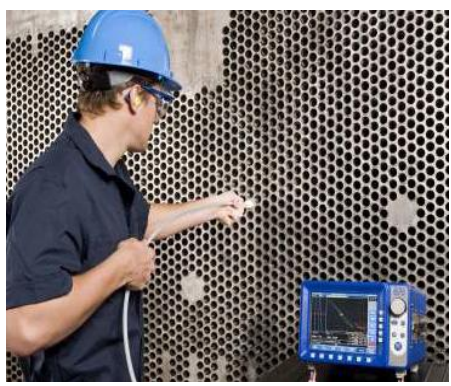

Figure -5 Eddy Current Test

ADVANTAGES:

- High speed examination with a bobbin loop

- Detects pits, breaks, wear, divider diminishing and that's only the tip of the iceberg

- Repeatable assessment

- Reliable information

\section{DISADVANTAGES:}

- It is difficult to find out the circumferential cracks with conventional bobbin Exam

- Cost of the eddy current test is high.

. Highly qualified technicians required to conduct the test.

\section{B. Air Leak Test}

To find out the probable causes of failure of the tube, it is essential that the exact location of each failure must be known. Before conducting air leak test in high pressure feed water heaters, tube and shell side water must be drained.

In this technique air is utilized as working medium. At first $0.2 \mathrm{~kg} / \mathrm{cm} 2$ air is to be applied on the shell side. The substance of the cylinder sheet is secured with cleanser water to distinguish any air spilling out of the open parts of the bargains with a disappointment. Whenever discovered air spill, close the two parts of the bargains utilizing elastic plugs. On the off chance that no cylinder breaks are seen, gradually increment the pneumatic force to a limit of $7.0 \mathrm{~kg} / \mathrm{cm} 2$. Utilizing the Probe to find the cylinder spill. Addition the test into the spilling tube. This will close wind stream the inclusion part of the bargain until the test has been embedded far enough to arrive at the purpose of disappointment.

When the test crosses the region of cylinder disappointment, air will victory of the plastic cylinder is to be submerged in water. An expanded progression of air pockets in the water demonstrates that a hole has been found. On the off chance that the disappointment is extremely little, air will quit blowing through the opposite part of the arrangement water radiator tube when the disappointment has been passed by the test seal.

On the off chance that the disappointment is for some time part, air will keep on smothering of the two closures until the test has been progressed over the opposite part of the bargain. The test is to be moved to and fro gradually to recognize the two parts of the bargains. The length of the disappointment is equivalent to the separation moved short $50 \mathrm{~mm}$. When a disappointment has been found the profundity of the break into the group is to be dictated by estimating the length of test embedded into the bombed cylinder. Where cylinders have bombed legitimately behind the cylinder sheet, especially consideration ought to be given to the cylinder to cylinder sheet joint[7],[9],[11].

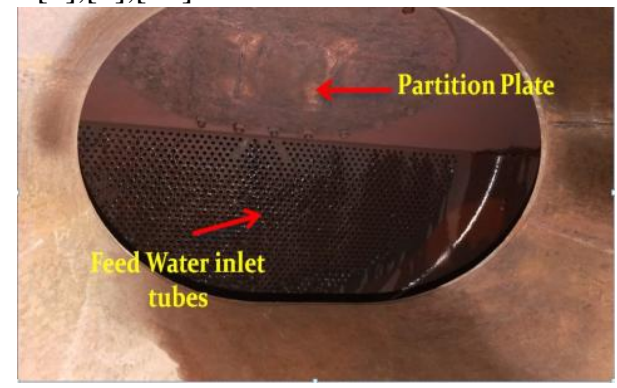

Figure 6 -View of water tubes in heater

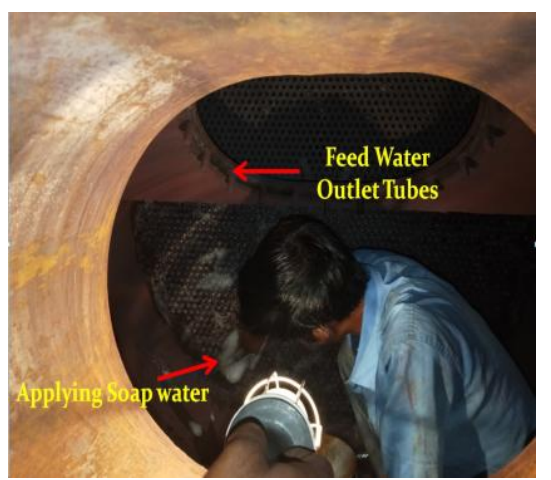

Figure - 7 Soap water test

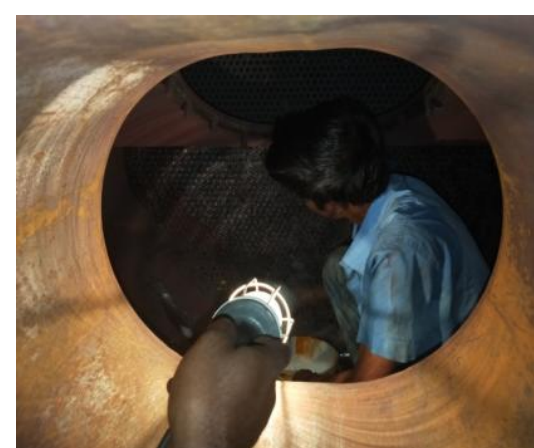

Figure 8 - Inspection of Water tubes 


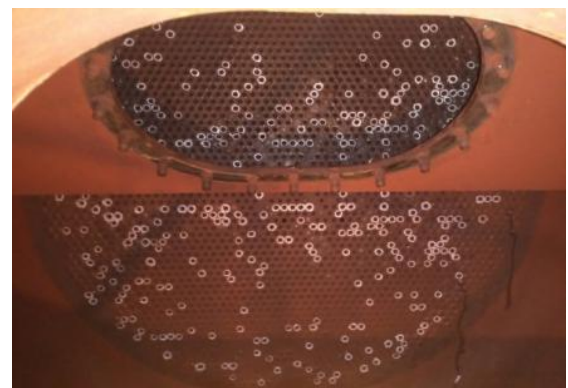

Figure - 9 Identified punctured tubes

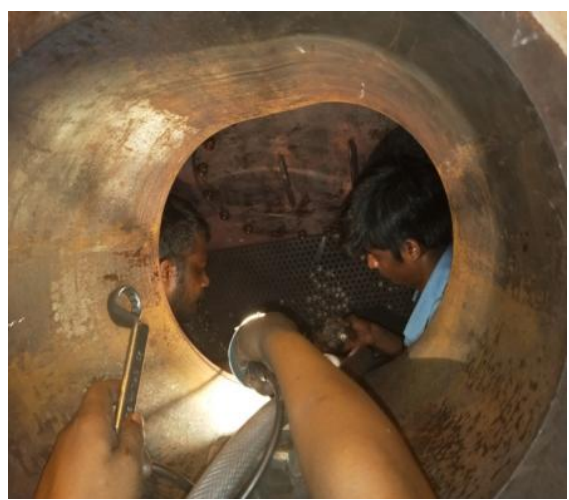

Figure - 10 Plugging of tubes

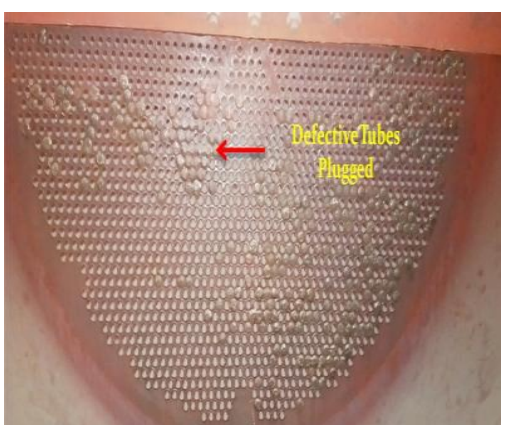

Figure - 11 Rectified Feed water tubes

\section{ADVANTAGES:}

1. It is simple strategy to discover the boundary disappointment of the cylinder

2. The expense of test relatively lesser than the Eddy Current Test

3. Highly qualified professionals not required to lead the test

\section{Visual Examination}

In some types of corrosion, visual examination can suggest the cause of failure and mechanism of attack. A photograph is usually recorded for subsequent reference and comparison of defects. Corrosion pitting of steel may be present in variety forms, it caused by dissolved oxygen in the working fluid. The pitting is commonly in the form of shallow oval pits overlaid with brown.

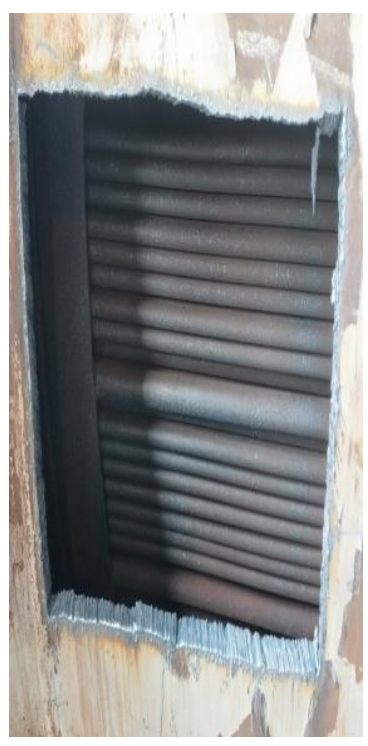

Figure - 12 Feed water Heater Tube Bundles

\section{Water Analysis}

In thermal power plant, feed water treatment is most important and requires careful water analysis. Chloride plays a critical role in pitting and crevice corrosion. It is better to maintain the chloride value in feed water is "null". If the value of chloride increases above the mentioned level the tubes will have localized corrosion[8],[10],[12].

\begin{tabular}{|c|c|c|c|c|c|c|c|c|}
\hline & $\begin{array}{l}\text { Con } \\
\text { duc } \\
\text { tivit } \\
\text { y } \\
\mu \mathrm{s} / \\
\mathrm{Cm}\end{array}$ & $\begin{array}{l}\text { PH } \\
\text { Val } \\
\text { ue }\end{array}$ & $\begin{array}{l}\text { Chlor } \\
\text { ide } \\
\text { ppm }\end{array}$ & $\begin{array}{l}\mathrm{Sio}_{2} \\
\text { ppb }\end{array}$ & $\begin{array}{l}\mathrm{NH}_{3} \\
\text { ppm }\end{array}$ & $\begin{array}{l}\mathrm{N}_{2} \mathrm{H} \\
4 \\
\text { ppm }\end{array}$ & $\begin{array}{l}\text { D } \\
\text { O } \\
\text { pp } \\
\text { b }\end{array}$ \\
\hline \multirow{3}{*}{$\begin{array}{l}\mathrm{Fe} \\
\text { ed } \\
\mathrm{W} \\
\text { at } \\
\text { er }\end{array}$} & $\begin{array}{l}\mathrm{M} \\
\mathrm{ax}\end{array}$ & 6.7 & 9.1 & 0.003 & Nil & 0.62 & 0.02 & 12 \\
\hline & $\begin{array}{l}\mathrm{M} \\
\text { in }\end{array}$ & 6.1 & 8.6 & Nil & Nil & 0.60 & 0.02 & 7 \\
\hline & $\begin{array}{l}\mathrm{Li} \\
\mathrm{mi} \\
\mathrm{ts}\end{array}$ & $\begin{array}{c}5 \text { to } \\
7\end{array}$ & $\begin{array}{l}8.8 \\
\text { to } \\
9.3\end{array}$ & NT & $<20$ & $<1.0$ & $\begin{array}{l}\leq \\
0.02\end{array}$ & $\begin{array}{l}< \\
10\end{array}$ \\
\hline
\end{tabular}

Table - 1 Feed Water Analysis

\section{E. Chemical Analysis}

Substance examination for cylinder tests taken from the faulty high weight feed water warmer is critical to recognize the level of changes in material combinations contrasted and unique rate [3]. It prompts evaluate the explanation of the harmed condition.

For instance, the carbon substance greatly affects the mechanical properties of the carbon and low amalgam steel tube material. Where any adjustments in carbon rate will prompt a general decrease in the mechanical properties of the cylinder material. Other decrease in the cylinder combinations like chrome substance affects the erosion obstruction of the cylinder material[13],[15],[17]. 


\section{F. Mechanical Analysis}

In high-temperature and high-weight power plant, Mechanical properties are the standard manual for the choice of materials for development of the plant [3]

On the off chance that any adjustment in plan mechanical properties of the material of the radiator, cylinder will influence the development capacities against boundary condition. For instance, the surface hardness means that the material capacity to oppose wear.

In the event that any decrease of surface hardness property, it will prompt decrease in the wear opposition of the cylinder material against fluids containing suspended solids which liable to causing disintegration.

\section{G. Macroscopic Scanning}

Broken down iron is a decent pointer of corrosivty of the feed water of the warm power plant. It happens when an expansion in the broke down oxygen, carbon dioxide, and smelling salts are available in the feed water of the power plant.

Broken up oxygen, which turns out to be exceptionally dynamic as the water temperature increments, will unit with the nuclear hydrogen, framing $\mathrm{H} 2 \mathrm{O}$ and creating the important cathodic response for dynamic erosion [3]. Oxygen erosion happens regularly as little pits and despondencies.

Hydrogen particle focus in water demonstrates the sharpness or alkalinity of the water. The hydrogen particle fixation is communicated as the $\mathrm{pH}$ esteem.

$\mathrm{pH}$ value of more than 7 indicates alkalinity, while less than 7 indicate acidity. $\mathrm{pH}$ value determines the intensity of corrosion [3].

\section{RESULTS}

Two types of experimental and various analysis are discussed. The first experimental employed to the inside damages of the heater tubes and second experimental employed to the outside damages of the heater tubes and also find out the defective location of the tube. Various analyses employed to the feed water passing through tube side sampling and the steam passing through the shell sampling.

From the results of Eddy current Test, Air leak test, visual inspection and laboratory investigation concerning the defective heater tubes, the following notes have been obtained:

\section{A.Eddy Current Test \\ From the Eddy current test, thicknesses of the heater tubes are measured and percentages of eroded tube thickness were noticed. Also weaker tubes are identified and plugged.}

From the air leak test, it was noticed outer diameter of the tube side defects in feed water heater and also exact location of the failure occurs in the tubes were measured. Also Tube to Tube sheets defects are identified.

\section{Visual Inspection}

From the visual inspection of the defective feed water heater tubes, most of the defects are found in the tubes in de-superheating zone and these tubes are severely affected in outer side of the tubes due to erosion and pitting problem.

\section{D.Water Analysis}

Chloride plays a critical role in pitting and crevice corrosion. High value of the chloride is observed in feed water. The chloride value in feed water is $0.003 \mathrm{ppm}$ while the recommended value is ' 0 ' ppm. This high value of chloride in feed water creates localized corrosion in feed water heater tubes[14],[16],[18].

High value of dissolved oxygen content is observed in feed water. The oxygen content in feed water range is 7 to $12 \mathrm{ppb}$, while the recommended value is less than $10 \mathrm{ppb}$.

\section{E. Chemical Analysis}

The results of chemical composition analysis in defective high pressure feed water heater tubes indicated that, the alloy material of tube show significant reduction in the alloy additive percentage as compared with that of the new tube[19],[21],[22].

\section{V.CONCLUSION}

1. From the above investigation of different kinds of high weight feed water radiator tube disappointment system, it was discovered that OD (outside distance across) disintegration is the significant sort of disappointment component. It prompts tube disappointment in high weight feed water warmer of warm power plant. The area of the most helpless to OD wear is in desuperheating zone at the passage of extraction steam. Indeed, even with the nearness of the impingement confuse over the cylinder group these sort of disappointment happens. From the visual assessment it is seen that, the most astounding influenced locale is close to edge of the confuse.

2. The gloom in the carbon substance and carbon isolation, which is Randomly dispersed all through the microstructure of the utilized cylinder, is the two primary driver of the downturn in the mechanical quality of the cylinder material, which quickens the OD disintegration instrument.

\section{B.Air Leak Test}




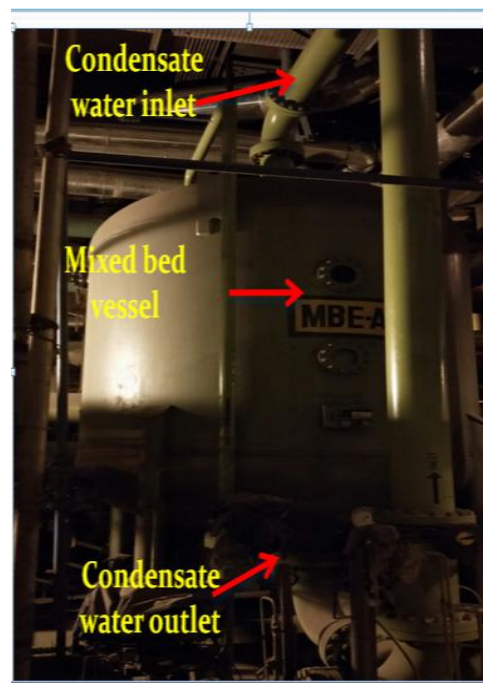

Figure - 13 Mixed bed Condensate polishing Unit

\begin{tabular}{|c|c|c|c|c|c|c|c|c|}
\hline & & $\begin{array}{l}\mathrm{Co} \\
\text { ndu } \\
\text { ctiv } \\
\text { ity } \\
\mu \mathrm{s} / \\
\mathrm{Cm}\end{array}$ & $\begin{array}{l}\text { PH } \\
\text { Val } \\
\text { ue }\end{array}$ & $\begin{array}{l}\text { Chlo } \\
\text { ride } \\
\text { ppm }\end{array}$ & $\begin{array}{l}\text { Sio2 } \\
\text { ppb }\end{array}$ & $\begin{array}{l}\mathrm{NH3} \\
\mathrm{ppm}\end{array}$ & $\begin{array}{l}\mathrm{N} 2 \mathrm{H} 4 \\
\mathrm{ppm}\end{array}$ & $\begin{array}{l}\text { DO } \\
\mathrm{ppb}\end{array}$ \\
\hline $\begin{array}{l}\mathrm{F} \\
\mathrm{e} \\
\mathrm{e}\end{array}$ & \begin{tabular}{|l}
$\mathrm{M}$ \\
$\mathrm{a}$ \\
$\mathrm{x}$
\end{tabular} & 6.7 & 9.1 & Nil & Nil & 0.62 & 0.01 & 7 \\
\hline $\mathrm{d}$ & \begin{tabular}{|l}
$\mathrm{M}$ \\
$\mathrm{i}$ \\
$\mathrm{n}$
\end{tabular} & 6.1 & 8.8 & Nil & Nil & 0.60 & 0.01 & 5 \\
\hline $\begin{array}{l}a \\
t \\
e \\
r\end{array}$ & \begin{tabular}{|l|}
$\mathrm{L}$ \\
$\mathrm{i}$ \\
$\mathrm{m}$ \\
it \\
$\mathrm{s}$ \\
\end{tabular} & $\begin{array}{l}5 \text { to } \\
7\end{array}$ & $\begin{array}{l}8.8 \\
\text { to } \\
9.3\end{array}$ & NT & $<20$ & $\begin{array}{l}< \\
1.0\end{array}$ & $\leq 0.02$ & $\begin{array}{l}< \\
10\end{array}$ \\
\hline
\end{tabular}

Table 2 - Feed water analysis with CPU

\section{RECOMMENDATIONS}

1. Provide isolation valve before the extraction valve for the steam in the shell side to avoid overheating of tubes resulted from steam passing the shell with the absence of feed water flowing through tubes.

2. Provide an-ion and cat-ion mixed bed condensate polishing unit (CPU) for removal of oozing chloride and removal of excess hydrogen ion concentration in condensate water (Table.2). The oozing chloride enter in to the condensate water is possible at condenser. This chloride creates localized corrosion in feed water heater tubes. Where using mixed bed condensate polishing unit, cat ion act as $\mathrm{H}+$ and Anion act as $\mathrm{OH}$. When condensate water enter into the CPU, all the chlorides are removed from water by cat -ion resins and these resins become as HCL and excess hydrogen ion concentrations are removed from water by an-ion resins and these resins become as $\mathrm{H} 2 \mathrm{O}$.

3. From the above investigation of different kinds of high weight feed water radiator tube disappointment system, it was discovered that OD (outside distance across) disintegration is the significant sort of disappointment component. It prompts tube disappointment in high weight feed water warmer of warm power plant. The area of the most helpless to OD wear is in desuperheating zone at the passage of extraction steam. Indeed, even with the nearness of the impingement confuse over the cylinder group these sort of disappointment happens. From the visual assessment it is seen that, the most astounding influenced locale is close to edge of the confuse.

4. The gloom in the carbon substance and carbon isolation, which is Randomly dispersed all through the microstructure of the utilized cylinder, is the two primary driver of the downturn in the mechanical quality of the cylinder material, which quickens the OD disintegration instrument.

\section{REFERENCES}

1. Tatikonda, N.C. \& Naveenchandran, P. 2019, "The behaviour of a compression ignition engine under the influence of diesel and microalgae biodiesel blends", International Journal of Mechanical and Production Engineering Research and Development, vol. 9, no. 4, pp. 447-456.

2. Tatikonda, N.C. \& Naveenchandran, P. 2019, "An experimental assessment on the impact of injection pressure on the characteristics of a diesel engine powered with the blend of diesel and microalgae biodiesel", International Journal of Engineering and Advanced Technology, vol. 8, no. 6, pp. 3284-3291.

3. Karthikeyan, S., Raman Balasubramanian, S.R., Ramesh, B., Raghul, S. \& Sathish Kumar, S. 2019, "The automatic solar tracker chronicles", International Journal of Recent Technology and Engineering, vol. 8, no. 1, pp. 312-315.

4. Hema, R., Sundararajan, M. \& Balaji, S. 2019, "Smartphone control robot with automatic firing gun", International Journal of Innovative Technology and Exploring Engineering, vol. 8, no. 9 Special Issue 3, pp. 625-627.

5. Saritha, B., Chockalingam, M.P. \& Aswathy, M. 2019, "Degradation of anionic dye using Fe/Tio2 composite by photocatalysis", International Journal of Innovative Technology and Exploring Engineering, vol. 8, no. 9 Special Issue 3, pp. 788-791.

6. Saritha, B., Maria Subashini, L. \& Aswathy, M. 2019, "Utilization of spent coffee grounds for compost production", International Journal of Innovative Technology and Exploring Engineering, vol. 8, no. 9 Special Issue 3, pp. 908-910.

7. Fernando, J.K., Meikandaan, T.P. \& Hemapriya, M. 2019, "Better utilisation of bottom ash in coal fired thermal power station", International Journal of Innovative Technology and Exploring Engineering, vol. 8, no. 9 Special Issue 3, pp. 898-900.

8. Kumar, K.S., Kiruthiga, K. \& Thendral, S. 2019, "Experimental analysis on fractional substitution of bond by utilizing rice husk cinder", International Journal of Innovative Technology and Exploring Engineering, vol. 8, no. 9 Special Issue 3, pp. 1163-1165.

9. Vignesh, P., Madan, P., Mohankumar, D. \& Naveenchandran, P. 2019, "Optimization of four stroke c.i. engine performance by using statistical techniques (mathematical method)", International Journal of Recent Technology and Engineering, vol. 8, no. 2, pp. 1685-1691.

10. Bharanidharan, S., Sathiyamurthy, K. \& Sheeba, B. 2019, "Using co-precipitation method determining synthesis and characterization of fe doped zinc oxide nanoparticles", International Journal of Innovative Technology and Exploring Engineering, vol. 8, no. 9 Special Issue 3, pp. 705-707.

11. Jeevanandan, D. \& Vino, J.A. 2019, "Heat recovery from boiler blowdown water by using heat exchanger in thermal power plant", International Journal of Mechanical and Production Engineering Research and Development, vol. 9, no. 3, pp. 219-222.

12. Rakesh, N.L., Balambica, V. \& Kannan, S. 2019, "Biogas extraction from waste orange peel by digestion process", International Journal of Mechanical and Production Engineering Research and Development, vol. 9, no. 3, pp. 323-330. 
13. Meenakshi, C.M. \& Krishnamoorthy, A. 2019, "The mechanical characterization of mono and hybrid fiber reinforced composites using experimental and finite element analysis methods", International Journal of Mechanical and Production Engineering Research and Development, vol. 9, no. 3, pp. 189-196.

14. Mohankumar, D., Prem Jayakumar, M., Sabarsish, R. \& Naveen Chandran, P. 2019, "Modeling and experimental investigation on centrifugal blower by computational fluid dynamics", International Journal of Mechanical and Production Engineering Research and Development, vol. 9, no. 3, pp. 331-340.

15. Balambica, V., Deepak, V. \& Kumar, S. 2019, "Design and efficiency of an asymmetric gear", International Journal of Mechanical and Production Engineering Research and Development, vol. 9, no. 3, pp. 223-230.

16. Manavalan, S., Balakrishnan, G. \& Ramasubramaniam, S. 2019, "An effect of cobalt oxide nano additive with biodiesel blends using cidi diesel engine", International Journal of Mechanical and Production Engineering Research and Development, vol. 9, no. 3, pp. 211-218.

17. Golden Renjith Nimal, R.J., Sivakumar, M. \& Esakkimuthu, G. 2019, "An investigation on mechanical properties and microstructure of $\mathrm{mg} / \mathrm{al}$ alloys using $\mathrm{zn}$ interlayer during diffusion bonding", International Journal of Mechanical and Production Engineering Research and Development, vol. 9, no. 3, pp. 125-130.

18. Hariharan, R., Raja, R. \& Vasu, S. 2019, "Mechanical and tribological behaviour of thin tan coating produced on AISI 1018 substrate by DC magnetron sputtering", International Journal of Recent Technology and Engineering, vol. 7, no. 6, pp. 591-598

19. Manavalan, S., Rai, R., Kumar, R.R., Chaudhary, R.K. \& Chaudhary, S.K. 2019, "Impact of modified piston - A review", International Journal of Recent Technology and Engineering, vol. 8, no. 6, pp. 616-620.

20. Manavalan, S., Gopi, A., Arivarasu, J., Abishek Ahi, A. \& Chandru, S. 2019, "Review on ceramic disc brake system", International Journal of Recent Technology and Engineering, vol. 7, no. 6, pp. 612-615.

21. Sabarish, R. \& Jeya Kumar, M.P. 2019, "The design and analysis of piston - Steady state thermal analysis using "ansys"", International Journal of Mechanical and Production Engineering Research and Development, vol. 9, no. 3, pp. 197-204.

22. Ravi, D. 2019, "CFD simulation of solar loading in car", International Journal of Mechanical and Production Engineering Research and Development, vol. 9, no. 3, pp. 231-236.

\section{AUTHORS PROFILE}

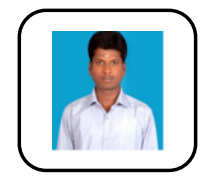

S. Manavalan Assistant Professor, Department of Mechanical Engineering, Bharath Institute of Higher Education and Research, Chennai, India.

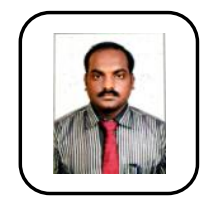

Manikandan J Assistant Professor, Department of Mechanical Engineering, Bharath Institute of Higher Education and Research, Chennai, India.

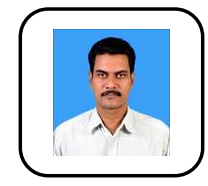

Nakkeeran S Assistant Professor, Department of Mechanical Engineering, Bharath Institute of Higher Education and Research, Chennai, India. 